\title{
Temporal variation in the spider assemblage (Arachnida, Araneae) in canopies of Callisthene fasciculata (Vochysiaceae) in the Brazilian Pantanal biome
}

\author{
Lúcia Yamazaki', Vanessa F. Vindica' ${ }^{1}$, Antonio D. Brescovit² \\ Marinez I. Marques ${ }^{3} \&$ Leandro D. Battirola'
}

\begin{abstract}
1. Programa de Pós-Graduação em Ciências Ambientais, Instituto de Ciências Naturais, Humanas e Sociais, Universidade Federal de Mato Grosso (UFMT) Av. Alexandre Ferronato, 1.200, 78557-267 Sinop, MT, Brazil. (lucia_yamazaki_ly@hotmail.com; v.francavindica@yahoo.com.br; Idbattirola@uol.com.br)

2. Laboratório Especial de Coleções Zoológicas, Instituto Butantan, Av. Vital Brasil, 1.500, 05503-900, São Paulo, SP, Brazil. (adbresc@terra.com.br)

3. Departamento de Biologia e Zoologia, Instituto de Biociências, Universidade Federal de Mato Grosso (UFMT), Av. Fernando Corrêa da Costa, s/n, 78060-900

Cuiabá, MT, Brazil. (marinez513@gmail.com)
\end{abstract}

\begin{abstract}
Spiders are generalist predators and present a high diversity of capturing and foraging, as well as considerable species richness in tropical habitats. Although, generally, not presenting specific relations to the host plant, they can be influenced by its phenology, structure and resource availability. So, this study analyzed temporal variation on the structure and composition of Araneae assemblage in Callisthene fasciculata (Spr.) Mart. (Vochysiaceae) canopies, in an area of monodominant vegetation, in the periods of high water, receding water, dry season and rising water in Pantanal of Mato Grosso, Brazil. The collection was performed on 24 individuals of $C$. fasciculata, six in each seasonal period, in 2010 and 2011, making use of canopy fogging with insecticide. For that, ten nylon funnels were distributed under each canopy of C. fasciculata individuals, in a total of $240 \mathrm{~m}^{2}$ of sampled canopies. In all, 3,610 spiders were collected and distributed in 24 families and 55 species. Anyphaenidae $\left(43.3 \% ; 6.5\right.$ ind. $\left./ \mathrm{m}^{2}\right)$, Pisauridae $\left(16.2 \% ; 2.4\right.$ ind. $\left./ \mathrm{m}^{2}\right)$, Araneidae $\left(12.7 \% ; 1.9\right.$ ind. $\left./ \mathrm{m}^{2}\right)$ and Salticidae $\left(12.4 \% ; 1.9 \mathrm{ind} . / \mathrm{m}^{2}\right)$ were the most representative. Osoriella tahela Brescovit, 1998 was the most abundant species $(12.2 \%)$. The nocturnal aerial runners of foliage $\left(45.6 \% ; 6.9 \mathrm{ind} . / \mathrm{m}^{2}\right)$, nocturnal aerial ambushers of foliage $\left(17.3 \% ; 2.6\right.$ ind. $\left./ \mathrm{m}^{2}\right)$, aerial orb weavers $\left(13.3 \% ; 2.0\right.$ ind.$\left./ \mathrm{m}^{2}\right)$ and the diurnal aerial runners of foliage $\left(12.5 \% ; 1.9\right.$ ind. $\left./ \mathrm{m}^{2}\right)$ spiders represented the most abundant guilds. Significant differences were observed in the composition of families and behavioral guilds, as well as abundance and richness among seasonal periods. The assemblage showed the highest abundance in receding water and highest species richness in high water period, probably related to the hydrologic cycle of the area and its influence on C. fasciculata phenology, indicating the importance of this plant species for spider's diversity maintenance in the Pantanal.
\end{abstract}

KEYWORDS. Arthropods, biodiversity, nebulization, wetlands.

RESUMO. Variação temporal na assembleia de aranhas (Arachnida, Araneae) em copas de Callisthene fasciculata (Vochysiaceae) no Pantanal brasileiro. Aranhas são predadoras, generalistas e apresentam elevada diversidade de estratégias de captura e forrageamento, bem como considerável riqueza de espécies em habitats tropicais. Apesar de, geralmente, não apresentarem relações específicas com hospedeiros vegetais, suas assembleias podem ser influenciadas pela fenologia, estrutura e disponibilidade de recursos sobre o hospedeiro. Assim, este estudo analisou a variação temporal na estrutura e composição da assembleia de aranhas em copas de Callisthene fasciculata (Spr.) Mart. (Vochysiaceae) em área de vegetação monodominante, ao longo dos períodos de cheia, vazante, seca e enchente na região norte do Pantanal de Mato Grosso, Brasil. As coletas foram realizadas sobre 24 exemplares de $C$. fasciculata, seis em cada período sazonal, em 2010 e 2011, empregando-se a termonebulização de copas com inseticida. Para a coleta, 10 funis de nylon foram distribuídos debaixo da copa de cada indivíduo de $C$. fasciculata, totalizando $240 \mathrm{~m}^{2}$ de copas amostradas. Ao todo foram coletadas 3.610 aranhas e distribuídas em 24 famílias e 55 espécies. Anyphaenidae (43,3\%), Pisauridae (16,2\%), Araneidae (12,7\%) e Salticidae (12,4\%) predominaram. Osoriella tahela Brescovit, 1998 foi a espécie mais abundante (12,2\% do total). As aranhas corredoras aéreas noturnas de folhagens (45,6\%), emboscadeiras noturnas de folhagens $(17,3 \%)$, tecelãs orbiculares aéreas $(13,3 \%)$ e as corredoras aéreas diurnas de folhagens $(12,6 \%)$ representaram as guildas mais abundantes. Diferenças significativas foram observadas na composição de famílias e agrupamentos em guildas comportamentais, bem como para a abundância e riqueza de aranhas entre os períodos sazonais. A assembleia apresentou maior abundância na vazante e maior riqueza de espécies no período de cheia, provavelmente relacionadas com o ciclo hidrológico da região e sua influência sobre a fenologia de C. fasciculata, indicando a importância desta espécie vegetal para a manutenção da diversidade de aranhas no Pantanal.

PALAVRAS-CHAVE. Artrópodes, biodiversidade, nebulização, áreas úmidas.

The high primary productivity of the forest canopy directly influences systemic functions, vital to the dynamics of terrestrial ecosystems (SHUKLa et al., 1990; BASSET et al., 2002). The plant architecture, floristic composition, and distribution of plant structures, besides the physiognomy of vegetation, are characteristics that define the canopy structure (MofFETt, 2000). Because of the large volume of food resources available to the fauna as well as nesting and shelter sites, the forest canopy harbors rich and complex animal communities, especially arthropods (ADIs et al., 2010; HsieH \& LinSENMAIR, 2011).

In the Pantanal biome of Mato Grosso State (Brazil), 
characterized by a strong seasonality, the structure of the canopy of forest areas varies between plant physiognomies with heterogeneous vegetation and monodominant formations (Nunes-DA-Cunha \& JunK, 2014). Monodominant formations are characterized by having more than $50 \%$ of individuals belonging to the same plant species, which significantly reduces the variety of species that make up the canopy (CONNELL \& LowMAN, 1989). This structural variation consequently can affect the distribution of resources and habitats for the fauna, considering that these habitats offer a three-dimensional array of substrates, physical and chemical, wet and dry, exposed or not, that directly receive the sun's energy (ERWIN, 2013). Variations in the distribution of abundance and richness of arthropods as a function of the type of forest and/or host, seasonal period, and taxonomic group evaluated were observed in studies of canopy assemblages in the Pantanal of Mato Grosso (SANTos et al., 2003; BATtiRola et al., 2004, 2005, 2014, 2016; MARQUES et al., 2006, 2007; YAMAZAKI et al., 2016).

Spiders generally do not have a direct relationship with plant hosts; however, they can be influenced indirectly by the structural conditions of the host (RAIZER \& AMARAL, 2001; SouZA \& MARTins, 2004, 2005; SouZa \& Módena, 2004), as well as by the presence as potential preys, often represented by herbivorous insects that feed on this host (COSTELLO \& DAANE, 1995; RINALDI \& ForTI, 1997; ARANGO et al., 2000). Many of these herbivores are distributed according to the plant phenology (flowering, fructification, and change of foliage), as well as changes in environmental conditions (WOLDA, 1988). Therefore, areas with high complexity in vegetation can present a larger variety of preys or more diversified sites for spiders to build traps and shelters (CARDOSO et al., 2011). Spiders are generalist and have varied strategies for hunting and capturing their preys, many of which are species-specific (HöFER \& BRESCOVIT, 2001; MoraIs et al., 2007). These different strategies increase their dominance and adaptability in different habitats, reducing the competition between species that compose the assemblage (e.g., MoRAN \& SouthwooD, 1982, PiANKA, 1994), which characterizes spiders as the main predators in these communities (CARDOSO et al., 2011) and thereby influences the dynamics of different populations in these habitats (FINKE \& DENNO, 2004).

Studies about the different plant species present in distinct vegetation formations in the Pantanal of Mato Grosso State have demonstrated the occurrence of specific spider assemblages, reflecting the complexity of the structure of habitats in that region (SANTOS et al., 2003; BATTIROLA et al., 2004, 2016), which are associated not only with the vegetation formation, but also with the intense hydrological seasonality brought about by the periodic flood pulse (JUNK et al., 1989; AdIs et al., 2010; NunES-DA-CUNHA \& JUNK, 2014). The present study, developed in a monodominant vegetation formation typical of the northern region of the Pantanal biome of Mato Grosso State, Brazil, evaluates (i) the composition and behavioral guilds of the assemblage of spiders associated with canopies of Callisthene fasciculata (Spr.) Mart. (Vochysiaceae); and (ii) the temporal variation in the composition, abundance and richness of this assemblage throughout the seasonal periods (high water, receding water, dry season, and rising water), during a single annual hydrologic cycle, in the northern region of the Pantanal of Mato Grosso, Brazil.

\section{MATERIAL AND METHODS}

Study area. Collections were performed on the Alvorada farm (16 $26^{\circ} \mathrm{S}$ and $\left.56^{\circ} 24^{\prime} \mathrm{W}\right)$, located in Poconé, in the northern region of the Pantanal biome of Mato Grosso State, Brazil. This region has well-defined seasons, with the rainy period occurring between October and March, and the dry spell between April and September, defining its hydrological cycle with four distinct seasonal periods (high water, receding water, dry season, and rising water) (HECKMAN, 1998). The high water period takes place between January and March, when seasonal floods occur, preceding the receding water stage (April to June). The dry season period is characterized by the low precipitation between July and September, lasting until the beginning of the rainy period, which characterizes the rising water period (October to December).

Sampling procedures were undertaken in a monodominant, seasonally flooded forest, with predominance of Callisthene fasciculata, known regionally as "carvoal". Callisthene fasciculata reaches between 4 and $15 \mathrm{~m}$ in height, and has a thick, dark, and highly rough bark (РотT \& Potт, 1994). The flowering period takes place between September and October, together with the dispersion of seeds generated in the previous year (CusTóDIO et al., 2014). It is a deciduous species with absent leaf fall during the periods of high water and receding water up to the beginning of dry season, followed by partial and total deciduousness that begins in the dry season and lasts until the beginning of the rising water period (CORSINI \& GUARIM-NETO, 2000).

Field procedures. Twenty-four canopies of $C$. fasciculata were fogged between 2010 and 2011. In each seasonal period (high water, receding water, dry season, and rising water), six C. fasciculata individuals were selected, keeping a minimum distance of $10 \mathrm{~m}$ between each sample. The criteria established by ADIs et al. (1998) and the methodological procedures of BATTIROLA et al. (2004) were used for the selection of the individuals. Initially, the area at the base of the trees was surrounded by 10 nylon collector funnels ( $1 \mathrm{~m}^{2}$ each) distributed according to the coverage and architecture of the canopy, covering a total sampling area of $240 \mathrm{~m}^{2}\left(10 \mathrm{~m}^{2}\right.$ per sampled tree). These funnels had a plastic collector bottle (one liter) at their base containing 92\% alcohol, and were suspended at around $1 \mathrm{~m}$ above the soil by ropes tied to the closest trees. During the high water period, funnels were suspended $1.5 \mathrm{~m}$ above the soil due to flooding of part of the forest (water depth ranging from 0.1 to $0.3 \mathrm{~m}$ ).

Fogging was performed for ten minutes in each tree, employing the synthetic pyrethroid lambda-cyhalothrin at $0.5 \%$, diluted in two liters of diesel oil at a concentration of 
$1 \%(20 \mathrm{ml})$, associated with the synergist (DDVP) at $0.1 \%$ ( $2 \mathrm{ml})$. The fog machine utilized was Swingfog SN50, which produces a strong squirt that is directed from the soil to all parts of the canopy. These procedures occurred always around 06h00min, which was the time of least intense air circulation, allowing the insecticide cloud to slowly ascend through the canopy and not disperse. Collector bottles containing the sampled materials were removed two hours after the application of the insecticide, which was the recommended time for its action (ADIS et al., 1998). The sampling took place in a single annual hydrological cycle in the Pantanal of Mato Grosso, and with were no annual replicas, this fact restricts analysis to the description of the temporal variation between the four seasonal periods evaluated.

Laboratory procedures. The material originating from the samples was transported to the Biological Collection of Southern Amazon (Acervo Biológico da Amazônia Meridional, ABAM), at the Universidade Federal do Mato Grosso, Sinop campus, MT, Brazil. Spiders were quantified and subsequently identified in the Laboratório Especial de Coleções Zoológicas (LECZ), at Instituto Butantan, São Paulo, SP, Brazil. Juvenile spiders were identified at the family level, while adult spiders could be identified further to a species or morphospecies level. Procedures described in DiAs et al. (2010), HöFER \& BRESCOVIT (2001), and UETZ et al. (1999) were adopted in the identification of the behavioral guilds. The reference material is deposited at LECZ, with duplicates in the Arachnida and Myriapoda Collection of ABAM.

Data analysis. So as to evaluate the variation in the composition of the families of the spider assemblage, as well as the groups of behavioral guilds, over seasonal periods (high water, receding water, dry season and rising water) indirect ordination was carried out by means of the Analysis of Principal Coordinates (PCoA) with data as to family abundance and grouping in behavioral guilds using the Chord distance measure (Euclidian Distance on Standardized Data). Subsequently, the two axis resulting from the ordering were used to test differenced in the composition of families and behavioral guilds of spiders between the seasonal periods by means of the Multivariate Analysis of Variance (MANOVA) adopting the Pillai test.

The richness of spider species at the assemblage was estimated using the Jackknife 1 method. So as to evaluate the temporal variation as to abundance and richness of spider species, initially the data were tested with regards to normality and homogeneity of variance applying the Shapiro-Wilk and Bartlett tests, respectively. The Analysis of Variance (ANOVA) test was applied so as to analyze the variation in the abundance and richness of spiders over the seasonal periods. So as to evaluate species richness immature individuals identified only at family level were excluded. The Tukey test a posteriori was used to identify the pairs that were significantly different from each other resulting from the analysis. For the analyses the software R, version 3.0.1 (R CoRe TeAm, 2013), with the Vegan package (OKSANEN et al., 2013) were used.

\section{RESULTS}

Assemblage composition. A total of 3,610 spiders in canopies of $C$. fasciculata were collected (15.0 ind./ $\mathrm{m}^{2}$ ), distributed into 24 families and 55 species (Tab. I). Of these, 3,380 (93.6\%) corresponded to juveniles and 230 (6.4\%) to adults, $53.9 \%$ of which (124 ind.) were female and $46.1 \%$ were male (106 ind.). Anyphaenidae (1,564 ind.; 43.3\%), Pisauridae (584 ind.; 16.2\%), Araneidae (459 ind.; 12.7\%), and Salticidae (447 ind.; $12.4 \%$ ) predominated over the other families. Theridiidae, Thomisidae, Corinnidae, Oonopidae, and Oxyopidae accounted for $12.3 \%$ of the sampled individuals (443 ind.; $1.8 \mathrm{ind} . / \mathrm{m}^{2}$ ). Together, the other families represented only 3.1\% (113 ind.; 0.5 ind./ $\mathrm{m}^{2}$ ) (Tab. I). For Amphinectidae, Gnaphosidae, Lycosidae, Miturgidae, Nephilidae, Oxyopidae, Pholcidae, Pisauridae, and Senoculidae, only juveniles were sampled. The 55 species obtained in the sampling represent $74.3 \%$ of the richness/ abundance expected by the Jackknife 1 estimator.

Araneidae (12 spp.), Theridiidae (10 spp.), Salticidae (9 spp.), Thomisidae (6 spp.), and Anyphaenidae (4 spp.) were families with a greater richness of species, representing $74.5 \%$ of the assemblage composition (41 spp.). Oonopidae is represented by three species, and Corinnidae and Mysmenidae by two species each. Dictynidae, Linyphiidae, Mimetidae, Selenopidae, Sparassidae, Tetrablemmidae, and Trechaleidae, by only one species each (Tab. I). The composition of the spider assemblies based on the abundance of families is variable over the seasonal periods evaluated. The two axis of the Analysis of Principal Components (PCoA) captured $63.8 \%$ of variation in the composition of the Araneae families. The indirect ordering as to the abundance date of the families between seasonal periods showed significant differences and therefore temporal variation in the structure of the assemblage (MANOVA, $\mathrm{F}=5.578 ; \mathrm{df}=3 ; \mathrm{p}<0.001$ ). This ordering indicated that the flood period is that which differs most from the others in relation to the composition of the families in the spider assemblage (Fig.1).

Behavioral guilds. The spider assemblage in canopies of $C$. fasciculata is composed of nine groups of behavioral guilds divided into hunters (2,315 ind.; $64.1 \%$; 9.6 ind. $\left./ \mathrm{m}^{2}\right)$ and weavers $\left(1,295\right.$ ind.; $35.9 \% ; 5.4$ ind. $\left./ \mathrm{m}^{2}\right)$. The hunters were distributed into six groups: nocturnal aerial hunters (1,646 ind.; 45.6\%), diurnal aerial hunters (455 ind.; 12.6\%), diurnal aerial ambushers (117 ind.; 3.2\%), nocturnal aerial ambushers (40 ind.; 1.1\%), nocturnal ground runners (38 ind.; $1.1 \%$ ), and ground runners (19 ind.; 0.5\%). Diurnal space web weavers (813 ind.; 22.5\%), orb weavers (481 ind.; $13.3 \%$ ), and nocturnal ground weavers ( 1 ind.; $<0.1 \%$ ) corresponded to the weaving spiders (Tab. I).

Hunting spiders were more abundant in relation to the weaving species in all seasonal periods. Ground-dwelling spiders, such as those which belong to the nocturnal ground weaver, ground runner, and nocturnal ground runner guilds, occurred in canopies of $C$. fasciculata at a higher frequency and abundance in the high water and rising water periods (Tab. I). The two axis of the Principal Component Analysis 
Tab I. Taxon, number of individuals (N), relative abundance (\%), and density (Ind./ $\left.\mathrm{m}^{2}\right)$ of spiders sampled in canopies of Callisthene fasciculata (Spr.) Mart. (Vochysiaceae) during the different seasonal periods in the northern region of the Pantanal biome of Mato Grosso State, Brazil, and their categorization into behavioral guilds (diurnal space web weavers (DSWW), orb weavers (OW), nocturnal ground weavers (NGW), diurnal aerial hunters (DAH), nocturnal aerial hunters (NAH), ground runners (GR), diurnal aerial ambushers (DAA), nocturnal aerial ambushers (NAA) and nocturnal ground runners (NGR)). *Identified at family level.

\begin{tabular}{|c|c|c|c|c|c|c|c|c|c|c|c|c|c|c|c|c|}
\hline \multirow{3}{*}{ Taxa } & \multicolumn{3}{|c|}{ High water } & \multicolumn{3}{|c|}{ Receding water } & \multicolumn{3}{|c|}{ Dry season } & \multicolumn{3}{|c|}{ Rising water } & \multicolumn{3}{|c|}{ Total } & \multirow{3}{*}{$\begin{array}{l}\text { Behavioral } \\
\text { guilds }\end{array}$} \\
\hline & $\mathrm{N}$ & $\%$ & Ind. $/ \mathrm{m}^{2}$ & $\mathrm{~N}$ & $\%$ & & $\mathrm{~N}$ & $\%$ & Ind. $/ \mathrm{m}^{2}$ & $\mathrm{~N}$ & $\%$ & Ind. $/ \mathrm{m}^{2}$ & $\mathrm{~N}$ & $\%$ & Ind. $/ \mathrm{m}^{2}$ & \\
\hline & & & $\left(60 \mathrm{~m}^{2}\right)$ & & & $\left(60 \mathrm{~m}^{2}\right)$ & & & $\left(60 \mathrm{~m}^{2}\right)$ & & & $\left(60 \mathrm{~m}^{2}\right)$ & & & $\left(240 \mathrm{~m}^{2}\right)$ & \\
\hline Amphinectidae & 1 & 0.1 & $<0.1$ & & & & & & & & & & 1 & $<0.1$ & $<0.1$ & NGW \\
\hline \multicolumn{17}{|l|}{ Anyphaenidae } \\
\hline Osoriella tahela Brescovit, 1998 & 20 & 2.6 & 0.3 & 1 & 0.1 & $<0.1$ & & & & 7 & 2.3 & 0.1 & 28 & 0.8 & 0.1 & $\mathrm{NAH}$ \\
\hline Otoniela sp. 1 & 1 & 0.1 & $<0.1$ & 2 & 0.1 & $<0.1$ & 1 & 0.1 & $<0.1$ & 3 & 1.0 & 0.1 & 7 & 0.2 & $<0.1$ & $\mathrm{NAH}$ \\
\hline $\begin{array}{l}\text { Xiruana pocone Oliveira \& } \\
\text { Brescovit, } 2015\end{array}$ & 9 & 1.2 & 0.2 & & & & & & & & & & 9 & 0.2 & $<0.1$ & $\mathrm{NAH}$ \\
\hline Anyphaenidae sp. 1 & 2 & 0.3 & $<0.1$ & 8 & 0.5 & 0.1 & 1 & 0.1 & $<0.1$ & & & & 11 & 0.3 & $<0.1$ & $\mathrm{NAH}$ \\
\hline Others * & 267 & 34.1 & 4.5 & 766 & 45.1 & 12.8 & 354 & 42.8 & 5.9 & 122 & 40.3 & 2.0 & 1,509 & 41.8 & 6.3 & $\mathrm{NAH}$ \\
\hline \multicolumn{17}{|l|}{ Araneidae } \\
\hline Acacesia sp. 1 & 2 & 0.3 & $<0.1$ & & & & & & & & & & 2 & 0.1 & $<0.1$ & OW \\
\hline Alpaida sp. 1 & & & & 1 & 0.1 & $<0.1$ & & & & & & & 1 & $<0.1$ & $<0.1$ & OW \\
\hline Araneus sp. 1 & 5 & 0.6 & 0.1 & & & & & & & & & & 5 & 0.1 & $<0.1$ & OW \\
\hline Araneus sp. 2 & & & & 1 & 0.1 & $<0.1$ & & & & & & & 1 & $<0.1$ & $<0.1$ & OW \\
\hline Bertrana sp. 1 & & & & & & & & & & 1 & 0.3 & $<0.1$ & 1 & $<0.1$ & $<0.1$ & OW \\
\hline Cyclosa sp. 1 & & & & 1 & 0.1 & $<0.1$ & & & & & & & 1 & $<0.1$ & $<0.1$ & OW \\
\hline Eustala sp. 1 & 4 & 0.5 & 0.1 & & & & & & & & & & 4 & 0.1 & $<0.1$ & OW \\
\hline Hypognatha sp. 1 & & & & 2 & 0.1 & $<0.1$ & & & & & & & 2 & 0.1 & $<0.1$ & OW \\
\hline $\begin{array}{l}\text { Kaira gibberosa O. Pickard- } \\
\text { Cambridge, } 1890\end{array}$ & & & & & & & 1 & 0,1 & $<0.1$ & & & & 1 & $<0.1$ & $<0.1$ & OW \\
\hline Metazygia sp. 1 & 3 & 0.4 & 0.1 & & & & & & & & & & 3 & 0.1 & $<0.1$ & OW \\
\hline Micrathena sp. 1 & 1 & 0.1 & $<0.1$ & & & & & & & & & & 1 & $<0.1$ & $<0.1$ & OW \\
\hline Araneidae sp. 1 & & & & 3 & 0.2 & 0.1 & & & & & & & 3 & 0.1 & $<0.1$ & OW \\
\hline Others & 94 & 12.0 & 1.6 & 191 & 11.3 & 3.2 & 131 & 15.8 & 2.2 & 18 & 5.9 & 0.3 & 434 & 12.0 & 1.8 & OW \\
\hline \multicolumn{17}{|l|}{ Corinnidae } \\
\hline Castianeirinae sp. 1 & 1 & 0.1 & $<0.1$ & & & & & & & & & & 1 & $<0.1$ & $<0.1$ & $\mathrm{NAH}$ \\
\hline Castianeira sp. 1 & 2 & 0.3 & $<0.1$ & & & & & & & & & & 2 & 0.1 & $<0.1$ & $\mathrm{NAH}$ \\
\hline Others & 14 & 1.8 & 0.2 & 7 & 0.4 & 0.1 & 23 & 2.8 & 0.4 & 1 & 0.3 & $<0.1$ & 45 & 1.2 & 0.2 & $\mathrm{NAH}$ \\
\hline Dictynidae & & & & & & & & & & & & & & & & \\
\hline Dictyna sp. 1 & 1 & 0.1 & $<0.1$ & & & & 1 & 0.1 & $<0.1$ & 3 & 1.0 & 0.1 & 5 & 0.1 & $<0.1$ & DSWW \\
\hline Others & & & & & & & 3 & 0.4 & 0.1 & 6 & 2.0 & 0.1 & 9 & 0.2 & $<0.1$ & DSWW \\
\hline Gnaphosidae & 4 & 0.5 & 0.1 & 2 & 0.1 & $<0.1$ & & & & & & & 6 & 0.2 & $<0.1$ & GR \\
\hline Linyphiidae & & & & & & & & & & & & & & & & \\
\hline Vesicapalpus sp. 1 & & & & & & & 1 & 0.1 & $<0.1$ & & & & 1 & $<0.1$ & $<0.1$ & DSWW \\
\hline Others & 1 & 0.1 & $<0.1$ & 1 & 0.1 & $<0.1$ & & & & 6 & 2.0 & 0.1 & 8 & 0.2 & $<0.1$ & DSWW \\
\hline Lycosidae & 3 & 0.4 & 0.1 & 1 & 0.1 & $<0.1$ & 1 & 0.1 & $<0.1$ & 5 & 1.7 & 0.1 & 10 & 0.3 & $<0.1$ & GR \\
\hline Mimetidae & & & & & & & & & & & & & & & & \\
\hline Mimetidae sp. 1 & & & & 1 & 0.1 & $<0.1$ & & & & & & & 1 & $<0.1$ & $<0.1$ & $\mathrm{NAH}$ \\
\hline Others & 1 & 0.1 & $<0.1$ & & & & 2 & 0.2 & $<0.1$ & 1 & 0.3 & $<0.1$ & 4 & 0.1 & $<0.1$ & NAH \\
\hline Miturgidae & & & & 2 & 0.1 & $<0.1$ & & & & & & & 2 & 0.1 & $<0.1$ & $\mathrm{NAH}$ \\
\hline Mysmenidae & & & & & & & & & & & & & & & & \\
\hline Mysmena sp. 1 & & & & 4 & 0.2 & 0.1 & & & & & & & 4 & 0.1 & $<0.1$ & OW \\
\hline Trogloneta $\mathrm{sp} .1$ & & & & & & & 2 & 0.2 & $<0.1$ & & & & 2 & 0.1 & $<0.1$ & OW \\
\hline Others & 1 & 0.1 & $<0.1$ & 12 & 0.7 & 0.2 & & & & 2 & 0.7 & $<0.1$ & 15 & 0.4 & 0.1 & OW \\
\hline Nephilidae & & & & & & & 1 & 0.1 & $<0.1$ & & & & 1 & $<0.1$ & $<0.1$ & OW \\
\hline Oonopidae & & & & & & & & & & & & & & & & \\
\hline Cinetomorpha sp. 1 & 3 & 0.4 & 0.1 & 2 & 0.1 & $<0.1$ & 1 & 0.1 & $<0.1$ & 3 & 1.0 & 0.1 & 9 & 0.2 & $<0.1$ & NGR \\
\hline Gamasomorphinae sp. 1 & 9 & 1.2 & 0.2 & 1 & 0.1 & $<0.1$ & & & & 11 & 3.6 & 0.2 & 21 & 0.6 & 0.1 & NGR \\
\hline Orchestina sp. 1 & 1 & 0.1 & $<0.1$ & & & & & & & & & & 1 & $<0.1$ & $<0.1$ & NGR \\
\hline Others & 3 & 0.4 & 0.1 & 2 & 0.1 & $<0.1$ & 1 & 0.1 & $<0.1$ & 1 & 0.3 & $<0.1$ & 7 & 0.2 & $<0.1$ & NGR \\
\hline Oxyopidae & 11 & 1.4 & 0.2 & 17 & 1.0 & 0.3 & 4 & 0.5 & 0.1 & 3 & 1.0 & 0.1 & 35 & 1.0 & 0.1 & DAH \\
\hline Pholcidae & & & & & & & 1 & 0.1 & $<0.1$ & & & & 1 & $<0.1$ & $<0.1$ & DSWW \\
\hline Pisauridae & 156 & 19.9 & 2.6 & 310 & 18.3 & 5.2 & 102 & 12.3 & 1.7 & 16 & 5.3 & 0.3 & 584 & 16.2 & 2.4 & DSWW \\
\hline Salticidae & & & & & & & & & & & & & & & & \\
\hline Acragas sp. 1 & & & & 3 & 0.2 & 0,1 & 1 & 0.1 & $<0.1$ & & & & 4 & 0.1 & $<0.1$ & $\mathrm{NAH}$ \\
\hline Freyinae sp. 1 & & & & & & & & & & 1 & 0.3 & $<0.1$ & 1 & $<0.1$ & $<0.1$ & $\mathrm{NAH}$ \\
\hline Frigga sp. 1 & 2 & 0.3 & $<0.1$ & & & & & & & & & & 2 & 0.1 & $<0.1$ & DAH \\
\hline Gastromicans sp. 1 & 3 & 0.4 & 0.1 & 1 & 0.1 & $<0.1$ & & & & 3 & 1.0 & 0.1 & 7 & 0.2 & $<0.1$ & $\mathrm{NAH}$ \\
\hline Gastromicans sp. 2 & 1 & 0.1 & $<0.1$ & & & & 6 & 0.7 & 0.1 & 1 & 0.3 & $<0.1$ & 8 & 0.2 & $<0.1$ & $\mathrm{NAH}$ \\
\hline Lyssomanes sp. 1 & 3 & 0.4 & 0.1 & 2 & 0.1 & $<0.1$ & & & & 1 & 0.3 & $<0.1$ & 6 & 0.2 & $<0.1$ & $\mathrm{NAH}$ \\
\hline Nycerella sp.1 & 2 & 0.3 & $<0.1$ & 4 & 0.2 & 0.1 & 2 & 0.2 & $<0.1$ & & & & 8 & 0.2 & $<0.1$ & DAH \\
\hline
\end{tabular}


Tab I. Cont.

\begin{tabular}{|c|c|c|c|c|c|c|c|c|c|c|c|c|c|c|c|c|}
\hline \multirow{3}{*}{ Taxa } & \multicolumn{3}{|c|}{ High water } & \multicolumn{3}{|c|}{ Receding water } & \multicolumn{3}{|c|}{ Dry season } & \multicolumn{3}{|c|}{ Rising water } & \multicolumn{3}{|c|}{ Total } & \multirow{3}{*}{$\begin{array}{l}\text { Behaviora } \\
\text { guilds }\end{array}$} \\
\hline & $\mathrm{N}$ & $\%$ & Ind. $/ \mathrm{m}^{2}$ & $\mathrm{~N}$ & $\%$ & Ind. $/ \mathrm{m}^{2}$ & $\mathrm{~N}$ & $\%$ & Ind. $/ \mathrm{m}^{2}$ & $\mathrm{~N}$ & $\%$ & Ind. $/ \mathrm{m}^{2}$ & $\mathrm{~N}$ & $\%$ & Ind. $/ \mathrm{m}^{2}$ & \\
\hline & & & $\left(60 \mathrm{~m}^{2}\right)$ & & & $\left(60 \mathrm{~m}^{2}\right)$ & & & $\left(60 \mathrm{~m}^{2}\right)$ & & & $\left(60 \mathrm{~m}^{2}\right)$ & & & $\left(240 m^{2}\right)$ & \\
\hline Synemosyna sp. 1 & 3 & 0.4 & 0.1 & 1 & 0.1 & $<0.1$ & & & & & & & 4 & 0.1 & $<0.1$ & $\mathrm{NAH}$ \\
\hline Salticidae sp. 1 & 1 & 0.1 & $<0.1$ & 4 & 0.2 & 0.1 & & & & 1 & 0.3 & $<0.1$ & 6 & 0.2 & $<0.1$ & $\mathrm{DAH}$ \\
\hline Others & 82 & 10.5 & 1.4 & 164 & 9.7 & 2.7 & 116 & 14.0 & 1.9 & 39 & 12.9 & 0.7 & 401 & 11.1 & 1.7 & $\mathrm{DAH}$ \\
\hline \multicolumn{17}{|l|}{ Selenopidae } \\
\hline Selenops sp. 1 & & & & & & & & & & 1 & 0.3 & $<0.1$ & 1 & $<0.1$ & $<0.1$ & NAA \\
\hline Others & 7 & 0.9 & 0.1 & 3 & 0.2 & 0.1 & & & & 2 & 0.7 & $<0.1$ & 12 & 0.3 & 0.1 & NAA \\
\hline Senoculidae & 4 & 0.5 & 0.1 & & & & & & & & & & 4 & 0.1 & $<0.1$ & NAA \\
\hline \multicolumn{17}{|l|}{ Sparassidae } \\
\hline Polybetes sp. 1 & & & & & & & 1 & 0.1 & $<0.1$ & & & & 1 & $<0.1$ & $<0.1$ & NAA \\
\hline Others & 3 & 0.4 & 0.1 & 10 & 0.6 & 0.2 & 5 & 0.6 & 0.1 & & & & 18 & 0.5 & 0.1 & NAA \\
\hline \multicolumn{17}{|l|}{ Tetrablemmidae } \\
\hline Matta? sp. 1 & 2 & 0.3 & $<0.1$ & & & & & & & & & & 2 & 0.1 & $<0.1$ & GR \\
\hline Others & 1 & 0.1 & $<0.1$ & & & & & & & & & & 1 & $<0.1$ & $<0.1$ & GR \\
\hline \multicolumn{17}{|l|}{ Theridiidae } \\
\hline Anelosimus sp. 1 & 1 & 0.1 & $<0.1$ & & & & & & & 1 & 0.3 & $<0.1$ & 2 & 0.1 & $<0.1$ & DSWW \\
\hline $\begin{array}{l}\text { Chrysso pulcherrima (Mello- } \\
\text { Leitão, 1917) }\end{array}$ & 2 & 0.3 & $<0.1$ & 13 & 0.8 & 0.2 & 4 & 0.5 & 0.1 & & & & 19 & 0.5 & 0.1 & DSWW \\
\hline Chrysso sp. 1 & & & & 3 & 0.2 & 0.1 & & & & & & & 3 & 0.1 & $<0.1$ & DSWW \\
\hline Cryptachaea sp. 1 & 3 & 0.4 & 0.1 & & & & & & & & & & 3 & 0.1 & $<0.1$ & DSWW \\
\hline Dipoena sp. 1 & 1 & 0.1 & $<0.1$ & 1 & 0.1 & 0.0 & & & & & & & 2 & 0.1 & $<0.1$ & DSWW \\
\hline Episinus sp. 1 & 1 & 0.1 & $<0.1$ & & & & & & & & & & 1 & $<0.1$ & $<0.1$ & DSWW \\
\hline Faiditus sp. 1 & & & & 1 & 0.1 & $<0.1$ & & & & & & & 1 & $<0.1$ & $<0.1$ & DSWW \\
\hline aff. Phycossoma sp. 1 & & & & 1 & 0.1 & $<0.1$ & & & & & & & 1 & $<0.1$ & $<0.1$ & DSWW \\
\hline Theridion sp. 1 & 1 & 0.1 & $<0.1$ & 1 & 0.1 & $<0.1$ & & & & & & & 2 & 0.1 & $<0.1$ & DSWW \\
\hline Theridiidae sp. 1 & & & & 1 & 0.1 & $<0.1$ & & & & & & & 1 & $<0.1$ & $<0.1$ & DSWW \\
\hline Others & 19 & 2.4 & 0.3 & 108 & 6.4 & 1.8 & 38 & 4.6 & 0.6 & 5 & 1.7 & 0.1 & 170 & 4.7 & 0.7 & DSWW \\
\hline \multicolumn{17}{|l|}{ Thomisidae } \\
\hline $\begin{array}{l}\text { Aphantochilus rogersi } \mathrm{O} \text {. } \\
\text { Pickard-Cambridge, } 1870\end{array}$ & 1 & 0.1 & $<0.1$ & & & & & & & 1 & 0.3 & $<0.1$ & 2 & 0.1 & $<0.1$ & DAA \\
\hline Deltoclita sp. 1 & & & & & & & 1 & 0.1 & $<0.1$ & 3 & 1.0 & 0,1 & 4 & 0.1 & $<0.1$ & DAA \\
\hline Tmarus sp. 1 & 3 & 0.4 & 0.1 & 1 & 0.1 & $<0.1$ & & & & 1 & 0.3 & $<0.1$ & 5 & 0.1 & $<0.1$ & DAA \\
\hline Tmarus sp. 2 & 3 & 0.4 & 0.1 & & & & & & & 2 & 0.7 & $<0.1$ & 5 & 0.1 & $<0.1$ & DAA \\
\hline Tobias sp. 1 & & & & 1 & 0.1 & $<0.1$ & & & & & & & 1 & $<0.1$ & $<0.1$ & DAA \\
\hline Thomisidae sp. 1 & & & & 2 & 0.1 & $<0.1$ & 1 & 0.1 & $<0.1$ & & & & 3 & 0.1 & $<0.1$ & DAA \\
\hline Others & 9 & 1.2 & 0.2 & 34 & 2.0 & 0.6 & 22 & 2.7 & 0.4 & 32 & 10.6 & 0.5 & 97 & 2.7 & 0.4 & DAA \\
\hline \multicolumn{17}{|l|}{ Trechaleidae } \\
\hline $\begin{array}{l}\text { Syntrechalea syntrechaleoides } \\
\text { (Mello-Leitão, 1941) }\end{array}$ & 1 & 0.1 & $<0.1$ & & & & & & & & & & 1 & $<0.1$ & $<0.1$ & NAA \\
\hline Others & 3 & 0.4 & 0.1 & & & & & & & & & & 3 & 0.1 & $<0.1$ & NAA \\
\hline RICHNESS & 33 & 60.0 & & 28 & 50.9 & & 14 & 25.5 & & 17 & 30.9 & & 55 & 100.0 & & \\
\hline TOTAL & 782 & 100.0 & 13.0 & 1,697 & 100.0 & 28.3 & 828 & 100.0 & 13.8 & 303 & 100.0 & 5.1 & 3,610 & 100.0 & 30.1 & \\
\hline
\end{tabular}

(PCoA) captured $67.7 \%$ of the variation in the composition of guild clusters. The MANOVA result, which compares the scores of the PCoA axis showed distinct distribution in the nine guild groups over the four seasonal periods (MANOVA, $\mathrm{F}=2.866 ; \mathrm{df}=3 ; \mathrm{p}<0.020)$. Greater variation is evident during the flood period, compared to the other seasonal periods (Fig. 2).

Abundance and richness. The seasonal periods present assemblages of spiders which are different from each other, both in terms of abundance (ANOVA, $\mathrm{F}=9.174$; $\mathrm{df}=$ $3 ; \mathrm{p}<0.001$ ) and in terms of richness of species (ANOVA, $\mathrm{F}=12.470 ; \mathrm{df}=3 ; \mathrm{p}<0.001)($ Figs 3,4$)$. The Tukey test identified variations in the abundance of spiders between the low water and dry season, high water and dry season, high and rising water and high water and receding water period.

The greatest abundance of spiders was obtained during receding water season (1,697 ind.; 47.0\%; 7.1 ind. $/ \mathrm{m}^{2}$, representing 17 families and 28 species. Anyphaenidae,
Pisauridae, and Araneidae were predominant, while Theridiidae (7 spp.), Salticidae (6 spp.), and Araneidae (5 spp.) were the richest families. Miturgidae was the only family sampled only in this period. During the high water period, 782 spiders $\left(21.7 \% ; 3.3\right.$ ind.$\left./ \mathrm{m}^{2}\right)$ were collected, divided into 21 families and 33 species. Anyphaenidae, Pisauridae, and Araneidae predominated (72.1\%). The greatest richness of species was recorded in Salticidae (7 spp.), Theridiidae (6 spp.), and Araneidae (5 spp.). Amphinectidae, Senoculidae, Tetrablemmidae, and Trechaleidae individuals occurred exclusively in this period (Tab. I).

During the dry season period, 828 spiders $(22.9 \%$; 3.5 ind. $/ \mathrm{m}^{2}$ ) were collected, representing 17 families and 14 species. Anyphaenidae, Araneidae, and Salticidae corresponded to the most abundant taxa. As regards the richness, Salticidae (3 spp.), Anyphaenidae, and Thomisidae (2 spp. each) were the richest, whereas Nephilidae and Pholcidae occurred exclusively in this period (Tab. I). During 


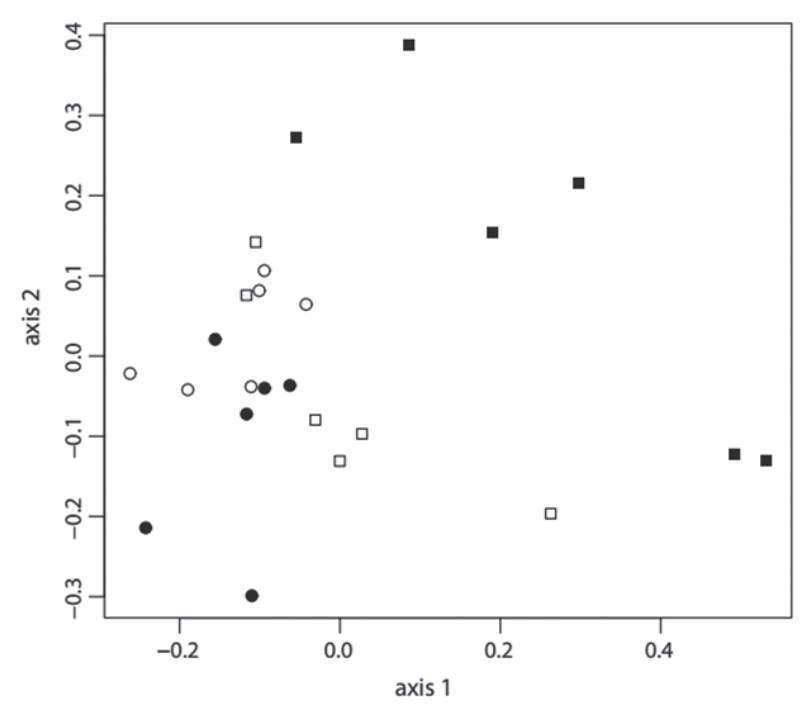

Fig 1. Comparison of scores of the PCoA axis generated from the distribution of 24 families composing the assemblage of spiders in canopies of Callisthene fasciculata (Spr.) (Vochysiaceae) between the different seasonal periods in the northern region of the Pantanal biome of Mato Grosso State, Brazil (๑, High water; $\bigcirc$, Receding water; $\square$, Dry season; $\mathbf{\square}$, Rising water).

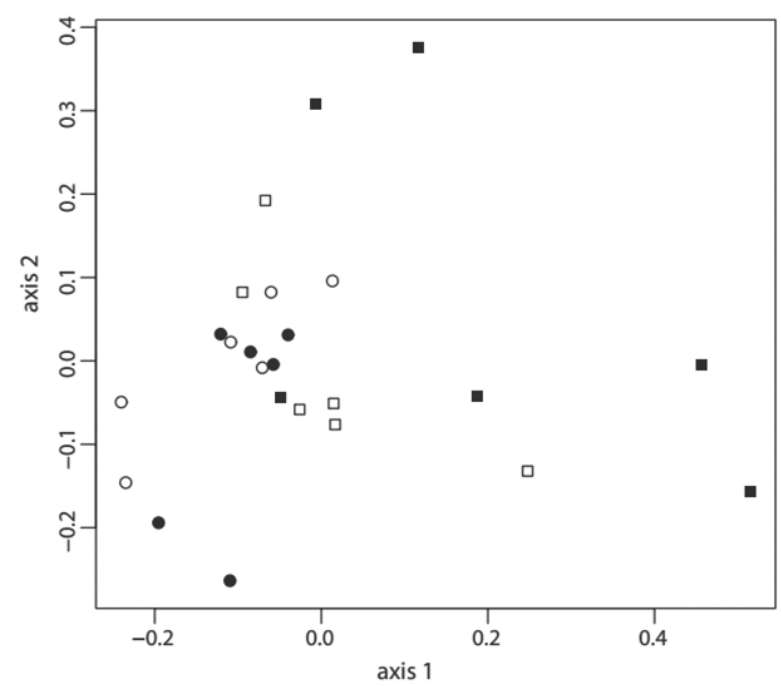

Fig 2. Comparison of scores of the PCoA axis generated from the distribution of nine groups in behavioral guilds of the assemblage of spiders in canopies of $C$. fasciculata between the different seasonal periods in the northern region of the Pantanal biome of Mato Grosso State, Brazil ( $\bullet$, High water; $\bigcirc$, Receding water; $\square$, Dry season; $\mathbf{\square}$, Rising water).

the rising water, the assemblage of Araneae was represented by 303 individuals $\left(8.4 \% ; 1.3\right.$ ind. $\left./ \mathrm{m}^{2}\right), 15$ families, and 17 species. The most abundant groups corresponded to Anyphaenidae, Salticidae, and Thomisidae. Salticidae (5 spp.), Thomisidae (4 spp.), and Anyphaenidae (2 spp.) displayed the greatest richness of species (Tab. I). Immature individuals predominate in relation to adults over all seasonal periods (Fig. 5).

\section{DISCUSSION}

The assemblage of spiders in canopies of $C$. fasciculata varies as a function of the seasonal periods, demonstrating

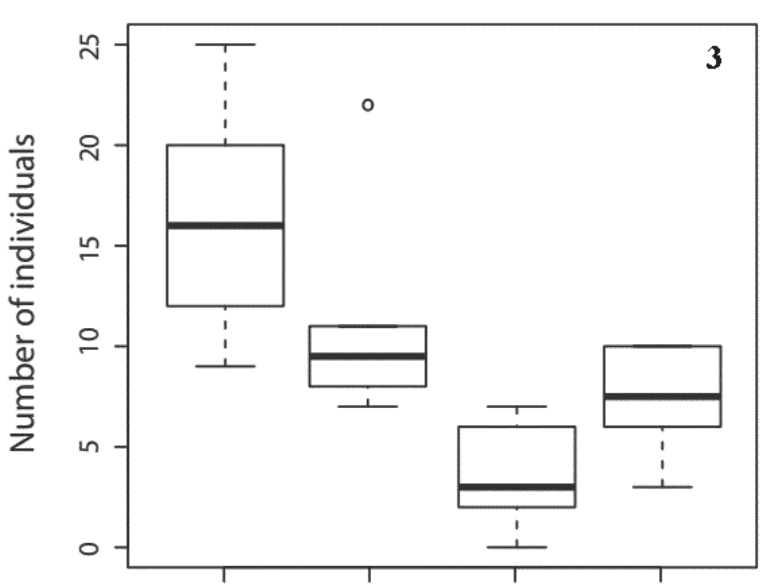

High water Receding water Dry season Rising water

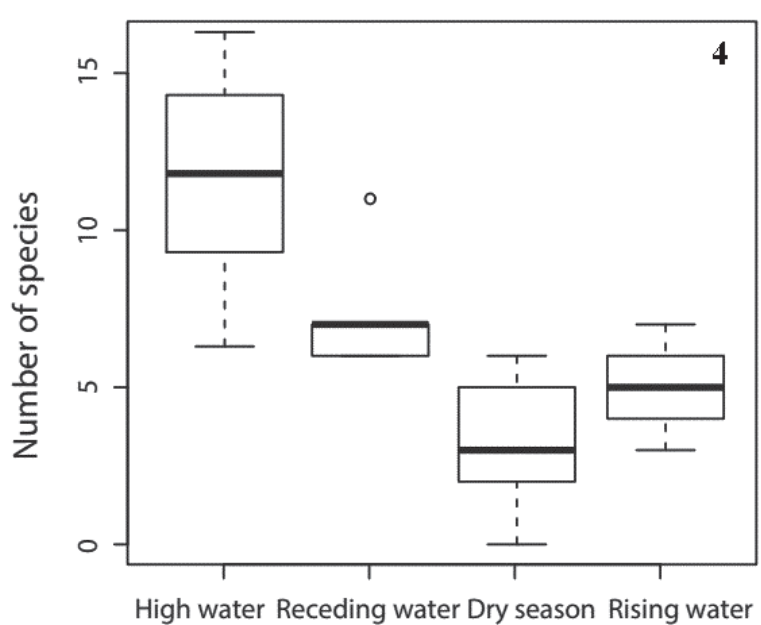

Figs 3, 4. Comparison between abundance (3) and richness (4) of the assemblage of spiders in canopies of $C$. fasciculata between the different seasonal periods in the northern region of the Pantanal biome of Mato Grosso State, Brazil.

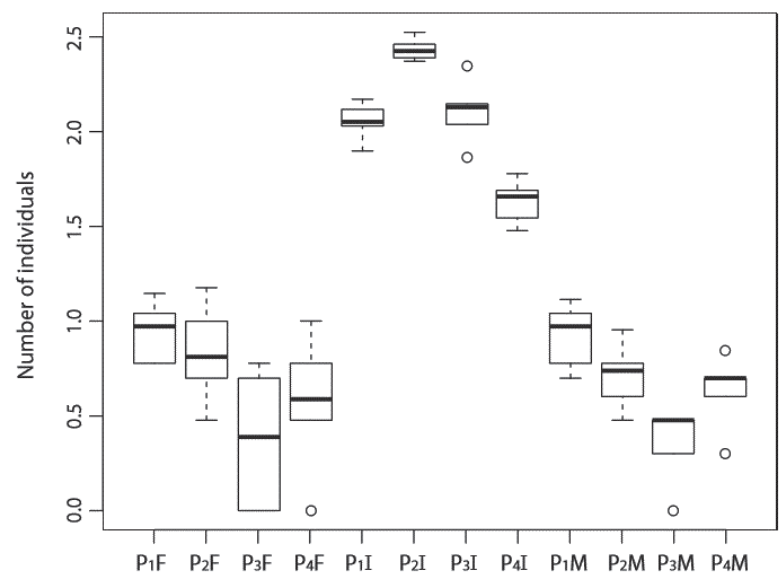

Fig 5. Comparison between abundance of juveniles and adults (females and males) of spiders in canopies of $C$. fasciculata between the different seasonal periods in the northern region of the Pantanal biome of Mato Grosso State, Brazil ( $\mathrm{P}_{1}$, High water; $\mathrm{P}_{2}$, Receding water; $\mathrm{P}_{3}$, Dry season; $\mathrm{P}_{4}$, Rising water; F, Females; M, Males; I, Immatures). 
alterations in the abundance, richness, and composition of the assemblage. The greatest variations were found to be in relation to the terrestrial (receding water and dry season) and aquatic (rising water and high water) stages, which are distinct because of the periodicity of alterations in the hydrological regimen (Heckman, 1998). These variations characterize the marked seasonality present in the Pantanal biome of Mato Grosso, which greatly influences the structure of habitats and consequently the fauna that makes use of them (JunK et al., 1989, 2006; BATTIROLA et al., 2009, 2016; NunES-DA-CUNHA \& JunK, 2014).

In the Pantanal, besides the variations in environmental conditions, the plant species have their phenology adapted to the cycles of drought and high water, influencing the species associated with them by variations in availability of niches, food, or shelter. These resources can vary seasonally, both in abundance and in quality (VAN-SCHAIK et al., 1993; ESPÍRITO-SANTO \& FERNANDES, 1998). The phenology of $C$. fasciculata is associated with the seasonal regimes (CORSINI \& GuARIm-Neto, 2000). During the terrestrial stage (dry season), this species has partial deciduousness followed by flowering, which alters the structure, productivity, and distribution of the canopy resources in its monodominant formations, as compared with the other seasonal periods. The restructuring of the canopy occurs with the restoration of the foliage at the beginning of rising water, and by the highwater and receding-water periods, it is completely formed (Corsini \& Guarim-Neto, 2000). For Souza \& Martins (2004), variations in plant phenology cause alterations in the spatial arrangement of the biomass, leading to alterations in the architecture of the branches, being able to affect the different species of animals that have some kind of interaction with the plant species.

The spider assemblage was more abundant during the receding water and dry season periods, when the canopy of the monodominant areas of $C$. fasciculata was completely formed, until the onset of leaf fall during the dry season. The periods of rising water and high water, however, are characterized by having the lowest abundance of spiders in this habitat. In addition to the variance in abundance, it was observed that the composition of the assemblage is distinct between seasonal periods. During the rising water and high water periods, there was the presence of typically edaphic taxa, with foraging characteristics, such as Lycosidae, Oonopidae, Gnaphosidae, Tetrablemmidae, and Amphinectidae (47 ind.; $81.0 \%$ of the total sampled for these families) on the ground. The fact that some of these taxa, e.g. Tetrablemmidae and Amphinectidae, were not sampled, in this habitat, in other seasonal periods, demonstrates the relationship between the edaphic fauna and the canopy of wetland forests of the Pantanal, caused by the temporary use of the canopy as a shelter throughout the flooding periods (BATTIROLA et al., 2009; Adis et al., 2001; YAMAZAKI et al., 2015). BATTIROLA et al. (2010) evaluated the spider assemblage in the soil of this same region of the Pantanal and reported that the activity of spiders is higher in the high water period (54.6 of the total recorded in the year), with Oonopidae (83.3\%) and Gnaphosidae (54.1\%) standing out. These authors associated the greater movement to the flood, which makes spiders and other invertebrates continuously move searching for a shelter, similarly to what was reported in Central Amazon (AdIs, 1997).

The presence of these typically edaphic taxa in the canopies of $C$. fasciculata causes the organization of the assemblage of the canopy, in these periods, to be differentiated from the other periods. Soil and canopies can be considered distinct habitats in tropical forests (e.g., SimON et al., 2003); however, in environments subjected to extreme variations in the environmental conditions such as wetlands, the displacement of edaphic community representatives seeking a shelter in the canopies, as well as of arboreal species that forage on the forest ground, generate the link between these forest strata (ADIs, 1997). In the Pantanal of Mato Grosso, ADIs et al. (2001) observed displacements from the soil to tree trunks during high water periods in Plusioporus salvadorii Silvestri, 1895 (Diplopoda: Spirostreptida), and Acromyrmex lundi carli Santschi, 1925 (Formicidae: Myrmicinae), which moves its nests from the soil to tree trunks. Displacements across soil, trunks, and tree canopies associated with the flood cycle were also observed in Polyxenida (Diplopoda) (BATTIROLA et al., 2009). A similar condition was observed in monodominant forest of Vochysia divergens Pohl. (Vochysiaceae), where the canopies are regarded as a refuge for soil dwelling spiders during rising water and high water periods (BATTIROLA et al., 2016), demonstrating the utilization of canopies as a temporary habitat during the floods of the Pantanal biome.

Regarding the composition of the spider assemblage, Anyphaenidae, Pisauridae, Araneidae, and Salticidae were the most representative taxa, as was already observed in the Pantanal (SANTOS et al., 2003; BATTIROLA et al., 2004, 2016), and in other ecosystems (Morais et al., 2007; CARVAlHo \& Avelino, 2010; Sena et al., 2010). The assemblage was characterized by the predominance of hunting over weaving spiders, similar to the results of BATTIROLA et al. (2004, 2016), CASTILHO et al. (2005), SENA et al. (2010), and Morais et al. (2007). The great variety of guilds present in the assemblage demonstrates the share and the lower overlapping of niches by the spiders. Despite all of them being predators, the use of different capture strategies reduces the competition and facilitates the coexistence between species, influencing the structuring of communities (SCHOENER, 1974; MorAN \& Southwood, 1982; PiAnKa, 1994; Wilson, 1999; Blondel, 2003; GILBERT et al., 2008), also demonstrating the variety and quantity of resources available in the habitat (HAwkINS \& MaCMahon, 1989).

Overall, the evaluation of the assemblage of spiders in canopies of $C$. fasciculata throughout the seasonal periods indicates that the high water and receding water periods encompass the greatest richness, probably influenced by the rainy season and the greater availability of resources in these periods, despite the reduction of habitats caused by the seasonal floods, which can trigger, for some spider 
taxa, the vertical dislocation from the soil to other habitats like trunks and canopies, as a survival strategy. Moreover, the variation in the phenology of $C$. fasciculata also exerts an effect, as it is a deciduous vegetation, and in the dry season and rising water periods, it shows alterations in the availability of micro-habitats and complexity of canopy structure, because it loses its leaves, unlike the high water and receding water periods, which are characterized for their greater complexity. This difference in conditions between the aquatic and terrestrial stages is responsible for providing a greater diversity of micro-habitats for the spider assemblage, allowing the survival of different species with different assemblage structures. Therefore, canopies of C. fasciculata can be characterized as important habitats for the maintenance of diversity of spiders in the Pantanal biome for harboring a rich and complex assemblage.

Acknowledgments. The authors thank the Environmental Sciences Graduate Program (PPGCAM/UFMT/Sinop); Coordenação de Aperfeiçoamento de Pessoal de Nível Superior (CAPES), for the Master's fellowship granted to the first author; Fundação de Amparo à Pesquisa do Estado de Mato Grosso, for the financial support (FAPEMAT, documents no. 737641/2008 and 155864/2015); and Núcleo de Estudos da Biodiversidade da Amazônia Mato-grossense (NEBAM), for the logistic support. This study was financially supported by CNPq (303028/2014-9) grant to ADB.

\section{REFERENCES}

ADIS, J. 1997. Estratégias de sobrevivência de invertebrados terrestres em florestas inundáveis da Amazônia Central: uma resposta à inundação de longo período. Acta Amazônica 27(1):43-54.

Adis, J.; Basset, Y.; Floren, A.; Hammond, P. \& Linsenmair, K. E. 1998. Canopy fogging of an overstory tree - recommendations for standardization. Ecotropica 4:93-97.

Adis, J.; Erwin, T. L.; Battirola, L. D. \& Ketelhut, S. M. 2010. The importance of Amazonian floodplain forests for animal biodiversity: Beetles in canopies of floodplain and upland forests. In: JUNK, W. J.; Piedade, M. T. F.; Wittmann, F.; Schöngart, J. \& Parolin, P. orgs. Amazon floodplain forests: Ecophysiology, biodiversity and sustainable management. Dordrecht, Springer 1, p.313-325.

Adis, J.; Marques, M. I. \& Wantzen, K. M. 2001. First observations on the survival strategies of terricolous arthropods in the northern Pantanal wetland of Brazil. Andrias 15:127-128.

Arango, A. M.; Rico-Gray, V. \& Parra-Tabla, V. 2000. Population structure, seasonality, and habitat use by the green lynx spider Peucetia viridans (Oxyopidae) inhabiting Cnidoscolus aconitifolius (Euphorbiaceae). Journal of Arachnology 28:185-194.

BASSET, Y.; Horlyck, V. \& WRIGHT, J. 2002. Forest canopies and their importance. In: Basset, Y.; Horlyck, V. \& Wright, J. eds. Studying forest canopies from above: The International Canopy Crane Network. Bogotá, Editorial Panamericana de Colombia, p.27-34

Battirola, L. D.; Marques, M. I.; Adis, J. \& Brescovit, A. D. 2004. Aspectos ecológicos da comunidade de Araneae (Arthropoda, Arachnida) em copas da palmeira Attalea phalerata Mart. (Arecaceae) no Pantanal de Poconé, Mato Grosso, Brasil. Revista Brasileira de Entomologia 48(3):421-430.

Battirola, L. D.; Marques, M. I.; Adis, J. \& Delabie, J. H. C. 2005. Composição da comunidade de Formicidae (Insecta, Hymenoptera) em copas de Attalea phalerata Mart. (Arecaceae) no Pantanal de Poconé, Mato Grosso, Brasil. Revista Brasileira de Entomologia 49(1):107-117.

Battirola, L. D.; Marques, M. I.; Brescovit, A. D.; Rosado-Neto, G. H. \& Anjos, K. C. 2010. Comunidade edáfica de Araneae (Arthropoda, Arachnida) em uma floresta sazonalmente inundável na região norte do Pantanal de Mato Grosso, Brasil. Biota Neotropica 10(2):173-183.
Battirola, L. D.; Marques, M. I.; Rosado-Neto, G. H.; Pinheiro, T. G. \& PINHO, N. G. C. 2009. Vertical and time distribution of Diplopoda (Arthropoda: Myriapoda) in a monodominant forest in Pantanal of Mato Grosso, Brazil. Zoologia 26(3):479-487.

Battirola, L. D.; Santos, G. B.; Rosado-Neto, G. H. \& Marques, M. I. 2014. Coleoptera (Arthropoda, Insecta) associados às copas de Attalea phalerata Mart. (Arecaceae) no Pantanal de Poconé, Mato Grosso, Brasil. EntomoBrasilis 7(1):20-28.

Battirola, L. D.; Batistella, D. A.; Rosado-Neto, G. H.; Brescovit, A. D. \& MARQUeS, M. I. 2016. Spider assemblage (Arachnida: Araneae) associated with canopies of Vochysia divergens (Vochysiaceae) in the northern region of the Brazilian Pantanal. Zoologia 33(4):e20150170. https://dx.doi.org/10.1590/S1984-4689zool-20150170

Blondel, J. 2003. Guilds or functional groups: does is matter? Oikos 100:223-231

Cardoso, P.; Pekár, S.; Jocqué, R. \& Coddington, J. A. 2011. Global patterns of guild composition and functional diversity of spiders. PLOS ONE 6(6):1-10.

Carvalho, L. \& Avelino, M. T. L. 2010. Composition and diversity of the spider fauna (Arachnida, Araneae) from Nazareth Farm, José de Freitas Municipality, Piauí, Brazil. Biota Neotropica 10(3):21-31.

Castilho, A. D.; Marques, M. I.; Adis, J. \& Brescovit, A. D. 2005. Distribuição sazonal e vertical de Araneae em área com predomínio de Attalea phalerata Mart. (Arecaceae), no Pantanal de Poconé, Mato Grosso, Brasil. Amazoniana 18(3-4):215-239.

ConNell, J. H. \& Lowman, M. D. 1989. Low-density tropical rain forests: some possible mechanism for their existence. The American Naturalist 134(1):88-119.

Corsini, E. \& Guarim-Neto, G. 2000. Aspectos ecológicos da vegetação de "carvoal (Callisthene fasciculata (Spr.) Mart.) no Pantanal matogrossense. In: Anais do III Simpósio sobre recursos naturais e socioeconômicos do Pantanal. Corumbá, Embrapa/UFMS, p.1-54.

Costello, M. J. \& DaAne, K. M. 1995. Spider (Araneae) species composition and seasonal abundance in San Valley Grape Vineyards. Environmental Entomology 24(4):823-831.

Custódio, L. N.; Carmo-Oliveira, R.; Mendes-Rodrigues, C. \& Oliveira, P. E. 2014. Pre-dispersal seed predation and abortion in species of Callisthene and Qualea (Vochysiaceae) in a Neotropical savanna. Acta Botanica Brasilica 28(3):309-320.

Dias, S. C.; Carvalho, L. S.; Bonaldo, A. B. \& Brescovit, A. D. 2010. Refining the establishment of guilds in Neotropical spiders (Arachnida: Araneae). Journal of Nature History 44(3-4):219-239.

ERwIN, T. L. 2013. Forest canopies, animal diversity. In: Levin, S. A. ed. Encyclopedia of Biodiversity. 2ed. San Diego, Academic Press, p. 511-515.

EsPírito-Santo, M. M. \& Fernandes, G. W. 1998. Abundance of Neopelma baccharidis (Homoptera: Psyllidae) galls on the dioecious shrub Baccharis dracunculifolia (Asteraceae). Environmental Entomology 27(4):870-876

Finke, D. L. \& Denno, R. F. 2004. Predator diversity dampens trophic cascades. Nature 429(6990):407-410.

Gilbert, B., Srivastava, D. S. \& Kirby, K. R. 2008. Niche partitioning at multiple scales facilitates coexistence among mosquito larvae. Oikos 117(6):944-950.

Hawkins, C. P. \& Macmahon, J. A. 1989. Guilds: the multiple meanings of a concept. Annual Review of Entomology 34:423-451.

Heckman, C. W. 1998. The Pantanal of Poconé: Biota and ecology in the northern section of the world's largest pristine wetland. Dordrecht, Kluwer Academic Publishers. 622p.

Höfer, H. \& BRESCOvit, A. D. 2001. Species and guild structure of a Neotropical spider assemblage (Araneae) from Reserva Ducke, Amazonas, Brazil. Andrias 15:99-119.

HSIEH, Y. L. \& LinSENMAIR, K. E. 2011. Underestimated spider diversity in a temperate beech forest. Biodiversity and Conservation 20(13):29532965.

Junk, W. J.; Bayley, P. B. \& Sparks, R. E. 1989. The flood pulse concept in river-floodplain systems. In: Dodge, D. P. ed. Proceedings International Large River Symposium (LARS). Ottawa, Department of Fisheries and Oceans, p.110-127.

Junk, W. J.; Nunes-da-Cunha, C.; Wantzen, K. M.; Petermann, P.; Strüssmann, C.; Marques, M. I. \& Adis, J. 2006. Biodiversity and 
its conservation in the Pantanal of Mato Grosso, Brazil. Aquatic Sciences 68(3):278-309.

Marques, M. I.; Adis, J.; Battirola, L. D.; Brescovit, A. D.; Silva, F. H. O. \& SiLVA, J. L. 2007. Variação sazonal na composição da comunidade de artrópodes associada à copa de Calophyllum brasiliense Cambess. (Guttiferae) no Pantanal mato-grossense, Mato Grosso, Brasil. Amazoniana 19(3-4):131-148.

Marques, M. I.; Adis, J.; SANtos, G. B. \& Battirola, L. D. 2006. Terrestrial arthropods from tree canopies in the Pantanal of Mato Grosso, Brazil. Revista Brasileira de Entomologia 50(2):257-267.

MofFetT, M. W. 2000. What's "up"? A critical look at the basic terms of canopy biology. Biotropica 32(4a):569-596.

Morais, R. M.; Оtт, R.; Отt, A. P. \& Redaelli, L. R. 2007. Aranhas e ácaros predadores em copas de tangerineiras Montenegrina, mantidas sob manejo orgânico, em Montenegro, RS. Neotropical Entomology 36(6):939-948

Moran, V. C. \& Southwood, T. R. E. 1982. The guild composition of arthropod communities in trees. Journal of Animal Ecology 51(1):289306.

NuNES-DA-CuNHA, C. \& JUNK, W. J. 2014. A classificação dos macrohabitats do Pantanal Mato-grossense. In: Nunes-DA-Cunha, C.; Piedade, M. T. F. \& JUNK, W. J. eds. Classificação e delineamento das áreas úmidas brasileiras e de seus macrohabitats. Cuiabá, EdUFMT. p.77-122.

Oksanen, J.; Blanchet, F. G.; Kindt, R.; Legendre, P.; Minchin, P. R.; O'hara, R. B.; Simpson, G. L.; Solymos, M. P.; Stevens, H. H. \& Wagner, H. 2013. Vegan: Community Ecology. Package. $\mathrm{R}$ package version 2.0-8. Available at $<\mathrm{http}$ //CRAN.R-project.org/ package $=$ vegan $>$. Accessed on 10 November 2014.

PiAnKA, E. R. 1994. Evolutionary ecology. New York, Harper Collins College Publishers. 486p.

Pотт, A. \& Pотт, V. J. 1994. Plantas do Pantanal. 5ed. Corumbá, EmbrapaSPI. 320p.

R Core Team. 2013. R: A language and environment for statistical computing. Austria, Vienna. R Foundation for Statistical Computing. Available at $<$ http: $/ /$ www.R-project.org/>. Accessed on 10 November 2014.

Raizer, J. \& Amaral, M. E. C. 2001. Does the structural complexity of aquatic macrophytes explain the diversity of associated spider assemblages? Journal of Arachnology 29(2):227-237.

RinAlDI, I. M. P. \& ForTI, L. C. 1997. Hunting spiders of woodland fragments and agricultural habitats in the atlantic rain forest region of Brazil. Studies on Neotropical Fauna Environment 32(2):244-255.
Santos, G. B.; Marques, M. I.; AdIs, J. \& Musis, C. R. 2003. Artrópodos associados à copa de Attalea phalerata Mart. (Arecaceae), na região do Pantanal de Poconé-MT. Revista Brasileira de Entomologia 47(2):211-224.

SCHOENER, T. W. 1974. Resource partitioning in ecological communities. Science 185(4145): 27-39.

Sena, D. U.; Peres, M. C. L.; Teixeira, R. R.; Domingos, B. S. \& Fontoura, T. 2010. Composição e guildas de aranhas (Arachnida: Araneae) em copas de um fragmento florestal urbano, Salvador, Bahia, Brasil. Revista Biociências 16(1):24-33.

ShuKla, J.; Nobre, C. \& Sellers, P. 1990. Amazon deforestation and climatic change. Science 247:1322-1325.

Simon, U.; Gossner, M. \& Linsenmair, K. E. 2003. Distribution of ants and bark-beetles in crowns of tropical oaks. In: BASSET, Y.; NovOTNY, V.; Miller, S. E. \& Kitching, R. L. Arthropods of tropical forest: Spatio-temporal dynamics and resource use in the canopy. Cambridge, Cambridge University Press, p. 59-68.

SouzA, A. L. T. \& Martins, R. P. 2004. Distribution of plant-dewelling spiders: Inflorescences versus vegetative branches. Austral Ecology 29(6):342-349.

SouzA, A. L. T. \& MARTins, R. P. 2005. Foliage density of branches and distribution of plant-dwelling spiders. Biotropica 37(3):416-420.

SouzA, A. L. T. \& Módena, E. S. 2004. Distribution of spiders on different types of inflorescences in the Brazilian Pantanal. Journal of Arachnology 32(2):345-348.

UetZ, G.; HaLAJ, J. \& CADY, A. B. 1999. Guild structure of spiders in major crops. Journal of Arachnology 27(1):270-280.

VAn-SChaik, C. P.; Terborgh, J. W. \& Wright, S. J. 1993. The phenology of Tropical Forests: Adaptive significance and consequences for primary consumers. Annual Review of Ecology and Systematics 24:353-377.

WiLson, J. B. 1999. Guilds, functional types and ecological groups. Oikos 86(3):507-522

WoldA, H. 1988. Insect seasonality: why? Annual Review of Ecology and Systematics 19:1-18.

YamaZaki, L.; Marques, M. I.; Brescovit, A. D. \& Battirola, L. D. 2015. Tityus paraguayensis Kraepelin, 1895 (Scorpiones: Buthidae) em copas de Callisthene fasciculata (Spr.) Mart. (Vochysiaceae) no Pantanal de Mato Grosso, Brasil. Acta Biológica Paranaense 44(3-4):153-158.

Yamazaki, L.; Dambroz, J.; Meurer, E.; Vindica, V. F.; Delabie, J. H. C.; Marques, M. I. \& Battirola, L. D. 2016. Ant community (Hymenoptera: Formicidae) associated with Callisthene fasciculata (Spr.) Mart. (Vochysiaceae) canopies in the Pantanal of Poconé, Mato Grosso, Brazil. Sociobiology 63(2):735-743 http://dx.doi.org/10.13102/ sociobiology.v63i2.824 